\title{
Miranda
}

Revue pluridisciplinaire du monde anglophone /

Multidisciplinary peer-reviewed journal on the English-

speaking world

5 | 2011

South and Race / Staging Mobility in the United States

\section{Burning Mississippi: Race, Fatherhood and the South in A Time to Kill (1996)}

\section{Hélène Charlery}

\section{OpenEdition \\ Journals}

\section{Electronic version}

URL: http://journals.openedition.org/miranda/2343

DOI: $10.4000 /$ miranda. 2343

ISSN: 2108-6559

Publisher

Université Toulouse - Jean Jaurès

\section{Electronic reference}

Hélène Charlery, "Burning Mississippi: Race, Fatherhood and the South in A Time to Kill (1996)",

Miranda [Online], 5 | 2011, Online since 29 November 2011, connection on 16 February 2021. URL:

http://journals.openedition.org/miranda/2343 ; DOI: https://doi.org/10.4000/miranda.2343

This text was automatically generated on 16 February 2021.

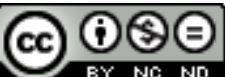

Miranda is licensed under a Creative Commons Attribution-NonCommercial-NoDerivatives 4.0 International License. 


\title{
Burning Mississippi: Race, Fatherhood and the South in A Time to Kill (1996)
}

\author{
Hélène Charlery
}

\section{Introduction}

1 In 1989, in Clanton, Mississippi, Jake Brigance, a young white local lawyer, is hired to defend Carl Lee Hailey, a black father charged with the murder of the two white men who savagely raped his ten-year-old daughter. This is the plot of Joel Schumacher's A Time to Kill, a Hollywood-made courtroom drama on race relations in Mississippi, adapted from John Grisham's first best-seller and autobiographical novel.

2 Not randomly, when A Time to Kill was released in American theaters, several movie critics disparagingly compared Joel Schumacher's film to the 1962 movie adaptation of To Kill a Mockingbird, Harper Lee's novel directed by Robert Mulligan. Hal Hinson from The Washington Post, called it a "stick, fast-paced and glamorously sexy [...] To Kill a Mockingbird with a blockbuster make-over" (Hinson). In Variety, Todd MacCarthy gave more credit to the film's cast than to "this sweaty Southern courtroom drama [with] its To Kill a Mockingbird setup" (MacCarthy). Rob Dreher, from the Sun Sentinel, laughed at this "visceral tale of a brave white lawyer trying to defend a black man in a racially charged Southern climate-A Time to Kill a Mockingbird" (Dreher). As Roger Ebert from Chicago Sun-Times rightfully argued in his review of the film, A Time to Kill raises interesting questions, "but they don't occur while you're watching the film" (Ebert).

Like To Kill a Mockingbird, A Time to Kill mixes three movie genres: the courtroom drama, the race movie and the southern film. Yet, while clinging to the filmic codes of the courtroom drama (Papke), both films play different cultural works regarding both race and the South. When To Kill a Mockingbird was released, Hollywood had ceased to portray Louisiana and Mississippi as the "romantic backdrops for films about the old South, the planter elite, riverboat gamblers, and showboats" (Cox 86). In films of the 
1930s, the comforting images of the southern upper class in a colorful landscape undeniably brought relief during the Depression years (Liénard-Yeterian 38). But by the mid-1940s, and most importantly in the 1950s and 1960s, the South had become the location where central characters defeated the region's institutional and collective racism in movies such as To Kill a Mockingbird and In the Heart of the Night (1967). Hollywood then provided a different stance both on racism and the region. A "backward South", correlated to "racism and tradition", was then adroitly distanced from "a modern or 'enlightened nation"” associated with democracy and change (Duck 3).

4 In her article, "Angel or Demon: Peforming the South in Cinema", Marie LiénardYeterian commented these binary visions of the South as an idyllic setting or as a land of evil and horror. As she put it

[t]he South has always provided a reservoir of images and narrative resources used by Hollywood to respond to certain national needs. [...] It projects idealized and comforting images by offering alternatives to distressing and current events, or it processes fears and anxieties generated by the news [...]. Filmic representations of the South provide emotional paradigms and elaborate psychological scripts that bring comfort either because they offer an outlet for certain fears or because they offer a comfortable distancing ("they" are not "us"). (Liénard-Yeterian 39-40)

5 The emergence of integration and message films coincided with what Francis M. Nevins called the "Golden Age of the law film" and the defense lawyer (Papke 474-475). Out of the three genres, Atticus Finch, because he defended a black man falsely accused of the rape of a white woman, facing an all-white jury in the Deep South, came out as a southern icon, a highly popular redemptive figure and "the most enduring fictional image of racial heroism" (Crespino 9).

The three movie genres were revived in the late 1980s and the 1990s, meanwhile trying to reenact Atticus Finch's racial heroism (Graham 17). In A Time to Kill, Carl Lee Hailey, played by Samuel L. Jackson, does not of course stand in the dusty blue overalls that Tom, the black defendant of To Kill a Mockingbird, wore facing the judge next to Atticus Finch. Yet, though wearing a red tie on a white shirt, he similarly stands next to Jake Brigance, his white defense lawyer, whose costume strangely resembles Gregory Peck's in the 1962 movie adaptation.

7 Yet, as Donald Bogle put it in Toms, Coons, Mulattoes, Mammies, and Bucks: An Interpretative History of Blacks in American Films, while the 1960s and 1970s movies denounce southern racism, "the subconscious goal of the 1980s may often have been to rid American films of the late 1960s/early 1970s [black] rebellious figures" (Bogle 269). Therefore, when Hollywood addressed the race theme by the late 1980s and 1990s, it actually "flirted [with it] but avoided a full examination of the subject" mainly because its history of the black population was centered on how it was experienced and explored by the white central characters (Bogle 301-316).

8 Indeed, Mississippi Burning (1989) and Ghosts of Mississippi (1996) illustrate Hollywood's 1980s and 1990s efforts at "whiten[ing] the southern past", which implied cinematically rereading of the civil rights movement and era "from the perspective of white [male] officers and lawyers" (Barker and McKee 10-11). It allowed Hollywood producers and filmmakers to redefine "white masculine heroism" in the post-Reagan era, by showing how the moral and human values behind the hero's individual actions illustrated the best of American contemporary values (Jeffords 118). In addition, Atticus Finch's liberal heroism was built by the combined efforts he put to defeat southern racism in court 
and to bring a moral message to his son and his daughter at home. Therefore, the 1990s reenactment of the Atticus Finch-heroism reinforced the conservative values of the father-figure as a central element of the family structure.

9 This article seeks to examine this cinematic conservative rereading of white masculinity and fatherhood in A Time to Kill's South. The examination of how the film depicts the two southern white men who rape the black little girl will lead to discuss the portrayal of the region. This first negative characterization is concomitant to the construction of the white liberal lawyer figure. However, despite the dichotomous categorizations of these figures, the acquittal of the black man in A Time to Kill leaves critical viewers with an ambiguous racial message that must be addressed eventually to understand how white male heroism is built through the film's positive images of manhood and fatherhood.

\section{The rednecks and the South}

10 In an article analyzing the evolving representations of the South from the first movie adaptation of John MacDonald's The Executioners in 1962 to the second adaptation released in 1991, Claire Dutrieux concludes that, since To Kill a Mockingbird and then Mississippi Burning, moviegoers have been accustomed to watching films in which the South "evolves in [racialist] fear" of others and reacts violently to it. Yet, movies after movies, it has been shifting from an Old South to a New one (Dutrieux 207). In A Time to Kill, the shift occurs with the assured death of the South's villains-representing the old South-and the moral transformation of the local community under the benevolent impact of the "redeemed" southern white lawyer, turning the region into a "New" South.

11 A Time to Kill brings out the issues of racial violence and racism in the South from the very beginning of the movie. But it distinguishes the two issues, by associating racial violence with the two white rapists on the one hand, and racism with the rest of the county's white community, on the other. The film depicts the two men as rednecks whose violence, spurred by drug and alcohol abuse, is racist, ignorant and gratuitous (Laurent 88). As Allison Graham put it in Framing the South: Hollywood, Television, and Race during the Civil Rights Struggle (2001)

the irrationally violent redneck is the indispensable convention of Hollywood's white redemption tales, the character whose essential, class-bound criminality is offered up, movie after movie, as proof of the inherent goodness of all other whites. (Graham 17)

12 The movie's introduction is purposely staged so as to bind the two rednecks' irrational racial violence and their criminality to "an inherent characteristic of class rather than race" (Graham 13). Several filmic devices used to insist on the two white men's negative cinematic presentation go further than John Grisham's description of the two rapists in the novel's first pages (Grisham 1-5).

13 The novel starts with the rape scene, but the latter only intervenes in the conclusion of the film's introduction scene. After a long still shot on the County's quiet country landscape, the pick-up truck of two men visually disturbs this quiet visual moment: the pick-up truck covers the entire landscape with the road dust it lifts on its full-blast ride. The quick pace of the editing and the close-ups on the drug they use while driving madly throughout the country, contrast sharply with the soundless images of the little 
girl in the black grocery store. The close-ups on the grocery list that she attentively follows insist on the idea that she is not just a child, but somebody's daughter. This cross-cutting effect is meant to bring a vivid contrast between the slow, quiet routine of the black characters and, on the other hand, the careless lifestyle and racist violence of the two rednecks, as they throw bottles of beer on the roof of a black inhabitant's house or on a basketball hoop while two black youngsters are casually playing ball.

The two men's despicable racist actions are filmed to distinguish them from the rest of Clanton's white community. The surprising look of the black inhabitants confronted with their gratuitous violence, their clothes or the close-ups on the four packs of beer that they buy at the same black grocery store are opposed to the wide long shot on Jake Brigance's house, at the precise moment when the latter walks out to go to work, followed on the house's porch by his lovely wife and daughter, and his dog. Thus, the film's two rednecks are cast in some form of racial marginality, because they disrupt the peaceful atmosphere in the black part of the County.

This racist violence visually prepares the audience to the rape scene that is preceded by the racist and sexual comments of the two rednecks as they stop by the young black girl who walks by herself on the country road. By the moment one of them throws a can of beer on her head, the viewers can only see the girl through shots on her body parts. They are visually encouraged to understand that after the passage of the two rednecks, Tonya has gone from an innocent black daughter grocery shopping to a dehumanized body.

16 The rape scene is depicted both through straight cuts and through a subjective camera showing the events as they are lived by the black girl: the cutting thus crosses shots on the sweating faces of the aggressors as they are seen by Tonya lying on the floor, and shots on parts of her body being touched by the two adults or tightened by the rope. The latter are meant to suggest the progression and the inevitability of the rape. While the audience can hear her constantly calling both her father and her mother during the rape, they can also hear the insults and death threats of the two rapists. The scene concludes on the rednecks' failed attempt at hanging the girl to a tree, whose branch breaks under the small body's weight. Thus, the rape scene is graphically staged so that the audience is visually disgusted by the physical presence of the rednecks on the screen after the rape.

17 Because the "spectacle of racial redemption" implies the "expulsion of the lawless redneck from southern society [so that] the moral purity of whiteness [...] is affirmed" (Graham 13), the violent death of the film's two rednecks is as much cinematically conventional as their irrational violence. Therefore, when Carl Lee Hailey storms out his M16 on his daughter's aggressors in the city's court hall, a slow-motion shot of the shooting scene seals the cinematic punishment of the two rednecks.

Yet, in the movie's introduction, the two men's own violence and racism, the violence of their arrest or of their death, are grounded in the South and the state of Mississippi. A sticker of the Confederate flag on the pick-up truck's rear window stands behind most shots on the two men's faces in the introduction scene; the flag is as well in the background of the out-of-town bar where Clanton's black sheriff arrests the two men. The dialogue between one of the white rapists and the black sheriff alters racial insults ("Blue gums, get out of here and grab a branch") and references insisting on the uniqueness of these two rednecks in the county ("unless there's another redneck asshole with a yellow truck.......with a Confederate flag"). The flag hung on the wall 
appears in the background on the shot when the white rapist utters "You go to hell nigger". Eventually, the vertical tracking shot after the shooting displays the two rapists' bloodstained bodies lying under the seal and motto of the state of Mississippi, Virtute et Armis ("By valor and arms") that covers the entire hall's floor.

Such graphic presentation of the state or these specific characters is not random: "The idea of Mississippi has functioned in the American imagination as a kind of holding bin for negative things about the nation" (Kathryn McKee quoted by Frazier). Likewise, in Hollywood race/South dramas, the state has become the location which epitomizes the South's "tradition and racism" (Duck 3). If there have indeed been changes in how race issues or the South had been depicted in Hollywood movies from Gone With the Wind (1939) to To Kill a Mockingbird (1962), this has also implied changes in the depictions of Hollywood's favorite locales, especially Mississippi.

Both limiting and inscribing the two rednecks' racial violence and their deaths to the state of Mississippi's Virtute et Armis localize or seclude these rednecks within the limits of the state. In A Time to Kill, the vertical tracking shot provides the viewers with Marie Liénard-Yeterian's idea of the "comforting distancing" role and function of the South as filmic object. This secures the cinematic idea that such racist violence can only erupt and be solved in the South, meanwhile providing the context in which white male heroism can be built to the audience.

Indeed the characterization of the two rednecks is accompanied with a graphic acceptance of racism or class distinction between the white and black inhabitants of the County. Before the trial's final summation, Carl Lee Hailey both defines and explains that racial line to Jake Brigance, meanwhile normalizing it:

We ain't no friends. We're on different sides of the line. I ain't never seen you in my part of town. You don't know where I live. Our daughters... ...won't play together. [...] You think just like them. [...] You're one of them, don't you see? You think you ain't because you eat in Claude's...and you're on TV talking about black and white. But the fact is...you're just like them. When you look at me, you don't see a man. You see a black man [...] You don't mean to be, but you are. It's how you's raised.

The movie indeed encourages viewers to perceive this racial separation, but it binds it to a class division. During the first scenes, the still shot on Jake Brigance's house in a middle class neighborhood invites the viewers to notice the contrast with the distanced houses of the black inhabitants, or to ponder at the fact that Tonya had to walk miles throughout the country to go to the nearest local grocery store. Similarly, the track-out at the end of the religious service Jake Brigance attends with his wife and family-in-law shows an exclusively white upper-middle class population in a plush church, which contrasts with the service in the following scene that only black inhabitants attend in a more modest church in another part of town. There are no white inhabitants witnessing Carl Lee Hailey walking out of his house bringing the shattered body of his daughter to the ambulance. Likewise, there are no black characters in the bar where the sheriff arrests the two white rapists.

A wide long shot on the customers at the Coffee Shop restaurant of the city center, before Jake Brigance is informed of Tonya's rape, depicts a significant racial organization of the extras. A black customer is indeed sitting at the counter of the restaurant in between white characters, and two black middle-class men sit in the middle of the shot, surrounded by other white customers sitting at their own tables. In the very background, an elderly black woman seems to be having breakfast with 
white women her age. Yet, the shot is too quick for the viewers to see without a pause. This very structured and conventional organization of the placing of the extras in the shot contrasts with the same quick wide long shot of the scene at Claude's, a more modest restaurant in the black part of the city, where only black customers are seen. In other words, in the city center, near the courthouse, characters of both races and of the same class do share the same place or space, because laws have changed and are now enforced, but there remain black and white parts of the southern town.

Most black characters of the film are poor, while most white characters are wealthy. The only poor whites are the two rednecks and those that are connected to them. Because none of the black characters commit gratuitous violent crimes, this dichotomous portrayal of race and class in the film's introduction leads to conclude that the two rednecks' social class indeed justifies both their racist violence and criminal behavior.

Because the redneck figure encapsulates all the racial bigotry of the Deep South, he is to be either redeemed by acknowledging such racist views or be killed as a punishment. On the other hand, the southern white lawyer will become the hero of this redemptive tale because he will have the capacity to "[transcend] the limits of [the southern] tradition and [attain] a liberal, morally rational racial viewpoint [...], seen as quintessentially American" (Crespino 9). It is through this character that the County's white community will eventually "[accept] responsibility for racism" (Graham 13). Thus, both figures serve the same purpose of satisfying and reassuring a national movie audience on the film's race message.

\section{The film's ambiguous racial message}

In "Like writing history with lighting': film historique/vérité historique", Robert A. Rosenstone claims that historic drama generally put individuals at the forefront of historical episodes, because the individualization of societal issues allows filmmakers to avoid addressing historical trauma on a collective basis, but rather to focus the viewers' attention on the personal solution or redemption of the central characters (Rosenstone 165). Like Rosenstone, Joseph Crespino brings a similar reading regarding race or southern movies:

$[\mathrm{H}]$ aving a white racial hero at the center of the story allows the public to conceptualize race issues within an individual, moralistic framework. If racism exists only on an individual basis, then racial reform can occur only through individual moral reform-not through social or structural change that might challenge the legal, economic, or political status quo. (Crespino 26)

Contrary to To Kill a Mockingbird, which insists on the influence of the spontaneous mob in the perpetration of racist violence and lynching in the 1960s Mississippi, the racial violence that erupts after the double manslaughter in the movie A Time to Kill is individualized. Jake Brigance's summation in the film differs from Atticus Finch's. Rather than promoting the impartiality of the American justice system as in To Kill a Mockingbird, Jake Brigance relies on the individual living experience of the members of the jury ("I want you to listen to yourselves."), not a collective thinking on race relations. A Time to Kill willfully leaves aside the pessimistic end of Harper Lee's novel or movie adaptation, concluding on Tom's death, only to focus the story on the white hero's individual construction: 
This is the strangeness of Atticus Finch's career: once a tool of liberal racial politics, Atticus has now become the pawn of racial conservatism. [...] As conservatives beatify the racial heroism of Atticus Finch, they fight the symptoms of the disease and fail to look for a cure that might get at the issue of white privilege [...]. (Crespino 26) from a white supremacist ideology that could be shared by the white inhabitants of the County. Instead, it is associated to characters that are either mere idiotic followers or motivated by criminal revenge. Although the viewers can watch Klan members foment different violent plans, they quickly learn that the Klan's influence has weakened and that most members are scattered in different counties throughout the state. In addition, the perpetration of this violence on screen is depicted as a single man's act, rather than by an organized group of men. The Klan is definitely eliminated from the city when the black sheriff handcuffs the three inhabitants who had joined the organization. But, the most surprising element of A Time to Kill's Klan members is that they only unleash their violence against the film's white characters.

Likewise, Joel Schumacher decided to give far less attention to the actions of the NAACP in the story than John Grisham did in his novel. The members of the organization are quickly estranged from the plot's ending as they are portrayed as being more interested in the black cause in the South than in Carl Lee Hailey or his family's sake. In A Time to Kill, the individualization of the white hero in the unfolding of the plot inevitably implies the filmic instrumentalization both of black characters and of racial tensions in the state as Roger Ebert's review of the film rightfully sums up: "the movie is interested in the white characters as people and the black characters (apart from Carl Lee Hailey) as atmosphere" (Ebert).

Criticisms had been voiced against Alan Parker's decision to center Mississippi Burning on the two white federal agents, Anderson and Ward, rather than depicting the efforts of the black local activists or the Justice Department ${ }^{1}$ :

In order to manufacture Anderson and Ward as independent heroes realizing the potential of a system of law, they need to be portrayed as taking the initiative in solving the murders and defying the white society that condoned them. The individual quality of their initiative would be lessened if the actual, documented work of the Justice Department on this case had been shown. (Jeffords 126)

Justifying his choice, Alan Parker claimed that he was trying to reach a wider audience, an "entire generation who knows nothing of that historical event [...] to cause them to react to it viscerally, emotionally, because of the racism that's around them now" (King). In 2000, historian Daniel Blake Smith remembered how he was asked to rewrite his script of a film project on the Greensboro Four. Rather than focusing on the "generational tension" or the "impatience of youth" that started the 1960s mass protest movement, the historian/screenwriter had to rewrite the script to center the story on an individual character-driven heroism, attract "a bankable adult star [...] cast in a prominent role", and appeal to "the likely demographic audience for the film" (Smith, 44), for his original script

showcased only the four young men. And there were no. 18-20 year old black actors who had the 'marquee value' to carry the film and attract an audience. Thus, the script needed a much stronger adult role which could be cast by a well-known black actor. (Smith 39) 

system that the movie ends on, it is of course not possible for Joel Schumacher's summer 1996 blockbuster to conclude on the conviction of a black father who killed the two white southern racist men who raped his ten-year-old daughter, or on the conviction of a part played by such a renowned black actor as Samuel L. Jackson. The "wider audience" argument would thus encourage filmmakers to believe that the viewers could only emotionally react to the films' historical and social themes if they are lived by a well-known actor (whether black or white) and told through the eyes of a white man.

Mississippi Burning (1988), A Time to Kill and Ghosts of Mississippi (1996) depict racial violence in a Mississippian context, in which white southern central characters are to solve crimes, and meanwhile enforce and protect American laws in the region. Their moral mission is endowed with a social duty, for they all embody official law abiding figures, whether it is a former local county sheriff turned FBI agent in Mississippi Burning, a lawyer in A Time to Kill, or a local prosecutor in Ghosts of Mississippi.

What indeed makes these race/South films so appealing and entertaining is that they show how their central white characters who originally share their local community's traditional Mississippian race-related values (as they are depicted in the films), "rebel" against these values and confront their traditional values to the American justice system. These southern white legal figures' "rebellion" originates in their desire to respect the rule of law after the acts of racial violence perpetuated in the story. They go through a revelation that they afterwards bring their entire community to, as illustrated by Jake Brigance's summation: "I tried to prove blacks could get a fair trial in the South... that we are all equal in the eyes of the law." ${ }^{2}$ Thus, both in Ghosts of Mississippi and in A Time to Kill, the viewer gets to exclusively witness the transformation of the traditional Mississippian into a liberal white southern lawyer.

In race/South/court drama movies, the final summation is generally handled by a middle-aged man, wise and experienced enough to invite the jury to "[transcend] the limits of that [southern] tradition", as Joseph Crespino put it (26). At the beginning of the film To Kill a Mockingbird, Atticus Finch already had what movie reviewers back in 1962 called a liberal charm (Crespino 9). Although the wise middle-aged and experienced white lawyer is also present in A Time to Kill, the redemptive mission is left to Jake Brigance. Being younger and played by Hollywood newcomer Matthew McConaughey, Jake Brigance's southern charm, his duty as a white liberal lawyer and role as a father must all be built. The film's viewers can easily appreciate Jake Brigance as a likeable naive and arrogant apprentice because they are convinced that by the end of the film, he will go through a moment of personal consciousness and become truly aware of the real meaning of the mission he has to carry on.

Despite poor reviews from the critics, A Time to Kill was a commercial success with nearly more than $\$ 110$ million at the box-office. The movie's plot may have been appealing to a national audience both influenced and divided along racial and class lines by the media spectacles of recent trials and their verdicts. A Time to Kill was indeed released four years after an all-white jury acquitted the four LAPD police officers who assaulted the black driver Rodney King in 1992, and two years after a mostly black jury found O.J. Simpson not guilty of the charges pressed against him during his criminal trial in 1994, while a mostly white jury found him guilty during the civil trial. 


\section{the text":}

[M]ost American readers and viewers take the renderings of courtroom trials for granted. They read about and watch courtroom trials without critically reflecting on them. The courtroom trial is a motif that delivers "meaning", and "meaning" is received without critical reflection. Americans are at ease with literary and cinematic courtroom trials, and they can use them to clarify their values, reinforce their moral standards, and even shape their identities (Papke 478).

Hailey because Wanda Womack, a white woman of the jury, asked them to imagine that the victim was a blue-eyed, fair-haired white little girl, and most importantly, that the rapists were two drunken black men (Grisham 513). In the film, the rape is narrated by Jake Brigance himself during his closing argument, not by a southern white woman trying to address the black male brute stereotype. What matters in A Time to Kill is not whether Carl Lee Hailey will be acquitted, but how Jake Brigance will win this acquittal. Thus, the latter is at the center of the plot's development and conclusion. The camera progressively zooms on his face, as he tries to hold up his tears when narrating the rape. The climax is when he tells the jury that, willing to get rid of the sole witness and victim of their crime, the two rapists threw her body over a bridge in a canyon, a last action which the viewers cannot see at the beginning of the film, during the rape scene. He concludes by inviting the jury to imagine that the little girl is white.

41 Yet, the reference to the potential drunken black rapists is taken out, and the jury is only invited to consider the atrocities lived by a white little girl, not the race of her aggressors, as is the case in the book. Thus, the novel's strategy goes further, because it also forces the white members of the jury to address collectively the signifying construction of black men as black male brutes.

Because he believes that this strategy invites the all-white jury to consider the defendant as a white father, Leonard Baynes concludes that: 
the main message in A Time to Kill is perhaps that only White men have legitimate reasons for taking the life of another White man [...], and [that] the only way that an all-White jury can justify the African American man's actions is by imagining that he is White. (Baynes 558) narrative, Carl Lee Hailey's character is treated differently, because his characterization creates a link between his act of murder, Jake Brigance's defense and the movie's construction of fatherhood. The gunfire occurs after the conversation Carl Lee Hailey has in Jake Brigance's office in which he tells him about the physical trauma Tonya will have to live with for the rest of her life. Immediately afterwards, he questions Jake Brigance's capacity to win his acquittal should he be in trouble, implicitly suggesting his intention to murder the two men. When Jake Brigance asks him what he intends to do, Carl Lee Hailey answers: "You got a daughter, Jake. What would you do?" By this moment of the film, although the two men are different on the racial and social levels, they are bound by their fatherhood.

The movie may leave critical viewers with such debatable racial message precisely because it uses race as a pretext to focus on the construction of fatherhood, as is illustrated by the image of Carl Lee Hailey after the acquittal, holding his daughter, in a low angle shot with the American and the Mississippian flags floating in the background. For that matter, Sarah Projansky provides another reading to Jake Brigance's strategy in his closing argument:

By asking the jurors to imagine a white girl being raped, [...] he simultaneously racializes and deracializes Tonya: he reminds the jury (and the audience) that she is African American and that the rape was racist, but he also insists that the violation of a man's child goes beyond race and racism, is a moral crime (against the father as much as against the daughter) that calls for the rapist's death (at the hands of the father). (Projansky 166)

She adds that the film's presentation of race, the staging of the rape and the characterization of the two rapists builds the story of a film 
in which an African American teaches a white man about his right, or rather his moral duty, to protect his daughter and to defend any other man who does so, regardless of race. Thus, while the film seems to "scream" "this story is about race!" throughout and while it depends on a gendered and racialized rape as narrative catalyst, in the end the film is most concerned with Jake's imagined role as avenger of the imagined rape of his (white) daughter. (Projansky 166) first conversation between Carl Lee Hailey and Jake Brigance ends with a cut that displays a shot on Jake Brigance's house. In the following scene which first depicts the lawyer as a father, he is seen putting his daughter to sleep, Carl Lee Hailey's line ("You got a daughter, Jake. What would you do?") lingers in the viewer's mind. The reverse angle shot shifts from the white father's serious face looking at his daughter to the close-ups on the sleepy fair-haired blue-eyed daughter. The filmic device and the ensuing conversation he has with his wife about the fact that looking at his daughter, he "cannot help but thinking about Tonya" prefigure his summation's conclusion, and continue building the relationship between Carl Lee Hailey and Jake Brigance as fathers.

The still shot on Carl Lee Hailey's entire family watching their father walk, without handcuffs, to the sheriff's car when he is put under arrest, insists on the fact that the black man's murder was tied to his fatherhood. Indeed, the scene repeats the same camera angle shots as when Carl Lee Hailey, earlier in the film, brought his daughter's body to the ambulance after the rape. The repetition of the camera angles is meant to associate his act to his moral duty as a father.

Other cleverly chosen and well-portrayed characters of the film support Carl Lee Hailey's duty as a father. When Deputy Dwayne Looney, the police officer accidentally shot during the gunfire, testifies during the trial, Jake Brigance, fearing that the now legless police officer publicly blame his client for his new condition, first refuses to cross-examine him. Carl Lee Hailey then forces his lawyer to do so, insisting he asked the deputy if he would send Carl Lee Hailey to jail. The Deputy does not answer as a police officer, but as a father ("I got a little girl. Somebody rapes her, he's a dead dog. I'll blow him away like Carl Lee did".), and concludes his testimony by shouting that Carl Lee Hailey is a hero.

51 The use of the film's female characters also supports that growing male bonding and fatherhood. Gwen Hailey and Carla Brigance, the black and white wives, reinforce both father-figures. Gwen Hailey is constantly depicted as a mother. When she intervenes in the film, her children, and more specifically Tonya and reminders of her physical trauma, are seen on the images:

Even when Tonya has been found and is with her mother, it is not until her father, Carl Lee Hailey, arrives that Tonya speaks and that the full horror of the event is articulated. When Carl Lee arrives, a close-up reveals his pained face as Tonya's mother cries offscreen and Tonya apologizes for dropping the groceries. (Projansky 165)

52 Therefore, although Tonya occupies most of the early images of the film, she is used afterwards as a pretext to systematically remind the audience of the reason why Carl Lee Hailey murdered the two white men. The aim is as well to set up Carl Lee Hailey's fatherhood and binds it to Jake Brigance's: "The emphasis [is put] on men's experience of the rape of" their "women, or more accurately" their "daughters" (Projansky 165).

In John Grisham's novel, Jake Brigance's daughter is taken away from the violent attacks directed against her father. Contrarily, in the film, the white daughter can hear 
the threatening phone calls paid to her father, the viewer is told that she comes home crying because she's been called a "nigger lover" by the other children at school and is the one who discovers the burning cross in front of their house. The white little girl is seen on screen whenever Jake Brigance's decision to defend a man who committed two cold-blooded murders is questioned by his wife and his family-in-law. The filmic victimization of the white daughter then accompanies Jake Brigance's belief that what happened to Tonya could have happened to Hannah. This is made more explicit when his wife returns:

I thought you took this case because you wanted to prove what a big time lawyer you were. But I was wrong. You took this case because if those boys had hurt Hannah the way they hurt Tonya you would've killed them too.

54 As Gwen Lee Hailey tells her husband in jail, "How you think you going to get money when you stuck in jail?" Jake Brigance is not only defending a black man facing an allwhite jury in the South. He needs to win Carl Lee Hailey's acquittal so that he can restore the latter in his fatherly position and himself in his own.

As all the female characters of the film are being victimized by physical violence or threats, the movie celebrates a powerful patriarchy and the rhetorical values of the family as they were portrayed in films of the Reagan and the Bush presidencies (Smith 77-80). The movie constantly builds images of masculinity and male heroism around the strong moral values of the father figure. At the end of the film, to Carl Lee's astonishment, Jake Brigance says the film's final line: "Just thought our kids could play together, Carl Lee." Though this line can be read as a message of hope in racial integration in the South, it is illustrating the cinematic victory of the movie's two father figures, for it is the values of fatherhood that victoriously restore peace and guarantee racial integration in the region.

\section{Conclusion}

A Time to Kill is a courtroom drama, a southern film, a race movie and a movie adaptation whose analyses bring out complementary readings of the film's conventional approaches to these genres' cinematic codes: the race question is seen through the white character; the final summation marks the narrative victory of the white law-figure; the South's rednecks are eliminated from the story's conclusion which allows this redemptive tale to protect the rest of the southern white community; the characterization of the central black character supports the narrative construction of the white hero. All these support the film's conservative central purpose: constructing white male heroism by binding it to the conservative values of a family structure grounded on victorious and strong images of fatherhood. 


\section{BIBLIOGRAPHY}

Barker, Deborah E. and Kathryn McKee. American Cinema and the Southern Imaginary. Athens, Georgia: University of Georgia Press, 2011.

Baynes, Leonard M. “A Time to Kill, the O.J. Simpson Trials, and Storytelling to Juries.” Loyola of Los Angeles Entertainment Law Review. 17:3 (1997) 549-569.

Bogle, Donald. Toms, Coons, Mulattoes, Mammies, and Bucks. An interpretative History of Blacks in American Films. New York: Continuum, 1999.

Cox, Karen L. Dreaming of Dixie. How the South Was Created in American Popular Culture. Chapel Hill: University of North Carolina Press, 2011.

Crespino, Joseph. “The Strange Career of Atticus Finch.” Southern Cultures 6:2 (2000) 9-29.

Dreher, Rob, “Time to Star: a Moral Tale, Memorable Performances” The Sun Sentinel 24 July 1996.

Duck, Leigh Anne. The Nation's Region: Southern Modernism, Segregation and U.S. Nationalism. Athens, Georgia: University of Georgia Press, 2006.

Dutrieux, Claire. "Deux Visions, Deux Sud ? Évolution de la représentation du Sud d'un Cape Fear à l'autre, 1962-1991”. In Le Sud au cinéma: De The Birth of a Nation à Cold Mountain. Dir. Marie Liénard-Yeterian et Taïna Tuhkunen. Palaiseau: Editions de l'Ecole Polytechnique, 2009. 197-208.

Ebert, Robert. “A Time to Kill”. RobertEbert.com/Movie Reviews. Chicago Sun-Times. Retrieved in June 2011.

<http://rogerebert.suntimes.com/apps/pbcs.dll/article?AID=/19960726/REVIEWS/607260302>

Fleming, Victor. Gone With the Wind. MGM. 1939.

Frazier, James. “Hollywood's Mississippi Remains a Brutal Backwater”. Daily Caller 18 September 2011.

Graham, Allison. Framing the South: Hollywood, Television, and Race during the Civil Rights Struggle. Baltimore: Johns Hopkins University Press, 2001.

Grisham, John. A Time to Kill. New York: Bantam Dell, 1989.

George, Nelson. “Black-And-White Struggle with a Rosy Glow”. New Tork Times 9 August 2011. Retrieved in August 2011.

< http://www.nytimes.com/2011/08/14/movies/black-and-white-struggle-through-hollywoodsrosy-glow.html?pagewanted=all>

Higashi, Sumiko. “Walker and Mississippi Burning: Postmodernism Versus Illusionist Narrative”. In Why Docudrama? Fact-Fiction on Film and TV. Ed. Allan Rosenthal. Carbondale, Illinois: Southern Illinois University Press, 1999. 340-356.

Hinson, Hal. “A Time to Kill: Justice Gets a Make-Over”. Washington Post 24 July 1996.

Jeffords, Susan. Hard Bodies: Hollywood Masculinity in the Reagan Era. New Brunswick, New Jersey: Rutgers University Press, 1994.

Jewison, Norman. In the Heart of the Night. United Artists. 1967.

King, Wayne. "Mississippi Burning: Facts vs. Fiction in Mississippi”. New York Times 4 December 1988. 
Laurent, Sylvie. "Le Poor White Trash ou la pauvreté odieuse du blanc américain". In "Sud(s), reconstructions" RFEA 120 (2009) : 79-95.

Lee, Harper. To Kill a Mockingbird. 1960. London: Arrow Books, 2006.

Liénard-Yeterian, Marie. "Angel or Demon: Performing the South in Cinema." In Le Sud au cinéma: De The Birth of a Nation à Cold Mountain. Dir. Marie Liénard-Yeterian et Taïna Tuhkunen. Palaiseau: Editions de l'Ecole Polytechnique, 2009. 38-52.

MacCarthy, Todd. “A Time to Kill”. Variety 10 July 1996.

Mulligan, Robert. To Kill a Mockingbird. Universal Studios. 1962.

Nicholson, Colin. "Hollywood and Race: To Kill a Mockingbird." In Harper Lee's To Kill a

Mockingbird. Ed. Harold Bloom. New York: Chelsea House Publishers, 2006. 65-74, 72-73.

Papke, David Ray. "Conventional Wisdom: The Courtroom Trial in American Popular Culture”. Marquette Law Review 82:3 (1999): 471-490.

Parker, Alan. Mississippi Burning. Orion Pictures. 1988.

Projansky, Sarah. Watching Rape: Film and Television in Postfeminist Culture. New York: New York University Press, 2001.

Reiner, Rob. Ghosts of Mississippi. Sony Entertainment. 1996.

Rosenstone, Robert A. "Like writing history with lighting': film historique/vérité historique". Vingtième Siècle. Revue d'histoire 46 (1995) : 162-175.

Schumacher, Joel. A Time to Kill. Warner Bros. 1996.

Smith, Carol R. "Gender and Family Values in the Clinton Presidency and 1990s Hollywood Film". In American Film and Politics from Reagan to Bush Jr. Eds. Philip John Davies and Paul Wells.

Manchester: Manchester University Press, 2002. 77-88.

Smith, Daniel Blake. "The (Un)Making of a Historical Drama: A Historian/Screenwriter Confronts Hollywood". The Public Historian 25:3 (Summer 2003): 27-44.

\section{NOTES}

1. As Sumiko Higashi put it, "claims to historical truth are vigorously debated because competing visions of the past are invoked to influence social attitudes and to shape public policy" (Higashi 350).

2. The entire summation may be watched on YouTube: http://www.youtube.com/ watch?v=C7f-BgDgpmE

\section{ABSTRACTS}

Inspired by the novel To Kill a Mockingbird and its movie adaptation (1962), A Time to Kill (1996) reenacts Atticus Finch's white liberal heroism, but provides a more conservative standpoint on 
masculinity and fatherhood. This article seeks to examine this cinematic conservative rereading by considering the film's different movie genres: the courtroom drama, the race movie, the southern film and the movie adaptation

Très largement inspiré du roman To Kill a Mockingbird et de son adaptation cinématographique mise en scène en 1962 par Robert Mulligan, A Time to Kill (1996) réactive la figure héroïque d'Atticus Finch, l'avocat blanc libéral du roman d'Harper Lee. Mais il en propose une lecture plus conservatrice, axée sur la construction du père comme ardent défenseur des valeurs de la famille et de la région. Cet article propose d'étudier cette relecture en tenant compte des différents genres cinématographiques auxquels le film appartient: le film de prétoire, l'adaptation cinématographique et les longs-métrages faisant du Sud un objet filmique ou mettant en scène des thématiques interraciales.

\section{INDEX}

Keywords: race, South, Mississippi, A Time to kill, To Kill a Mockingbird, Atticus Finch, white liberal lawyer, racial integration, racial violence, fatherhood

Mots-clés: appartenances raciales, représentations filmiques Sud / Mississippi, Redneck, avocat libéral blanc sudiste, paternité

\section{AUTHOR}

\section{HÉLÈNE CHARLERY}

Maître de Conférences

Université Toulouse 2 - Le Mirail

helene.charlery@free.fr 